Tao ZHANG ${ }^{1}$, Ping $\mathrm{LI}^{1}, \mathrm{Ci}_{\mathrm{FANG}}{ }^{1}$ and Rongfeng $\mathrm{JIANG}^{1 *}$

\title{
PHOSPHATE RECOVERY FROM ANIMAL MANURE WASTEWATER BY STRUVITE CRYSTALLIZATION AND $\mathrm{CO}_{2}$ DEGASIFICATION REACTOR
}

\author{
ODZYSKIWANIE FOSFORANÓW ZE ŚCIEKÓW OBORNIKA \\ ZA POMOCA KRYSTALIZACJI STRUWITU \\ I ODGAZOWANIA Z CO, W REAKTORZE
}

\begin{abstract}
The problem of phosphorus discharge is related to environmental protection and food security. Struvite crystallization is a useful technology for phosphate recovery from wastewater. In the research, struvite crystallization process with $\mathrm{CO}_{2}$ degasification continuous U-shape reactor (CUSR) was application for phosphate recovery from animal manure wastewater. The result indicated $\mathrm{PO}_{4}{ }^{3-}-\mathrm{P}$ recovery ratio could achieve $47-53 \%$ without magnesium addition when CUSR hydraulic retention time controlled at $60 \mathrm{~min}$. With extra magnesium addition, $\mathrm{PO}_{4}{ }^{3-}-\mathrm{P}$ recovery ratio could significant achieve $80-86 \%$ at magnesium addition amount $57.5 \mathrm{mg} / \mathrm{dm}^{3}$. PHREEQC modeling predictions trend of struvite crystallization was close to CUSR experimental results. The modeling calculation can provide a theoretical guide for operational parameters design. For seeding technology, high phosphate recovery efficiency was obtained and preformed struvite was the most effective seeding material. Surface characterization analysis demonstrated the dominant composition of chemical solids was struvite. Water extraction analysis indicated chemical solids recovery from animal manure wastewater could release $\mathrm{PO}_{4}{ }^{3-}-\mathrm{P}$ slowly and be available as slow-release fertilizer.
\end{abstract}

Keywords: animal manure wastewater, $\mathrm{CO}_{2}$ degasification, continuous U-shape reactor (CUSR), phosphate, struvite crystallization

\section{Introduction}

Phosphorus is one of most important non-renewable nutrients for sustain high crop yields. As the demand for phosphorus as fertilizers, the world's reserves are predicted to last for about 125 years [1]. Global phosphorus gradually scarce is one of the important challenges in the 21 st century [2]. Meanwhile, over enrichment phosphorus wastewater have discharged into water environment and related to eutrophication [3].

Animal manure wastewater, produced from livestock and poultry production, contains phosphate, nitrogen, carbonate, heavy metals, and chemical compounds as major

\footnotetext{
${ }^{1}$ Key Laboratory of Plant-Soil Interactions of Ministry of Education, College of Resources and Environmental Sciences, China Agricultural University, Beijing 100193, China, phone +861062731179

${ }^{*}$ Corresponding author: rfjiang@cau.edu.cn
} 
constituents. Animal manure wastewater can be utilized as liquid fertilizer in a previous age, but its transportation becomes less economical with increasing distance from the farm nowadays [4]. Therefore, the treatment of phosphate recovery from animal manure wastewater is directly linked to water environmental protection and agricultural food security.

Chemical precipitation, with metal ions of magnesium, calcium, iron, and aluminum, is a common method for phosphate recovery from wastewater. The choice of metal ions is related to recover phosphate for agricultural application, as a result magnesium-based application of forming struvite, can be available recycled as fertilizer, is a more promising technology [5]. Struvite is a white crystalline substance consisting of magnesium, ammonium and phosphate in equal molar concentrations. The basic chemical reaction to form struvite has been expressed in (1)

$$
\mathrm{Mg}^{2+}+\mathrm{NH}_{4}^{+}+\mathrm{H}_{\mathrm{n}} \mathrm{PO}_{4}^{3-\mathrm{n}}+6 \mathrm{H}_{2} \mathrm{O} \Leftrightarrow \mathrm{MgNH}_{4} \mathrm{PO}_{4} \cdot 6 \mathrm{H}_{2} \mathrm{O}+\mathrm{nH}^{+}
$$

Previous studies have done tests on struvite crystallization include reaction solution conditions, thermodynamic and kinetic studies, and computer models for variety wastewater treatment [6]. According to the composition of animal manure wastewater, struvite crystallization process can be used with $\mathrm{pH}$ adjustment and magnesium addition. However, high concentration of carbonate in animal manure wastewater will inhibit struvite crystallization and consume excess alkali and magnesium. In order to solve the problem, $\mathrm{CO}_{2}$ degasification process has been employed for decrease carbonate concentration and increase $\mathrm{pH}$ value for treatment of animal manure wastewater recently [7]. Korchef et al [8] demonstrated $\mathrm{CO}_{2}$ degasification technique could gentler increase $\mathrm{pH}$ for saving alkali and prevent other magnesium precipitates formation.

In practical application, crystallization reactor for struvite particles separated from effluent is an outstanding problem [9]. Several types of reactors, such as fluidized bed reactors, mechanical stirred reactors, were conducted to enhance the separation or collection of struvite particles $[10,11]$. In addition, seeding technology was developed to improve crystal nucleation and growth in crystallization reactor. Several kinds of seed materials such as preformed struvite [12], sand, or stainless steel structures were tested. Although crystallization reactor equipment for phosphate recovery has investigated for municipal and industrial wastewater treatment systems, its application was not common practice in animal manure wastewater treatment [7]. Only few research investigated $\mathrm{CO}_{2}$ degasification process of struvite crystallization in continuous reactor equipments for phosphate recovery from animal manure wastewater.

In our study, a $\mathrm{CO}_{2}$ degasification continuous U-shape reactor (CUSR) was developed for phosphate recovery from animal manure wastewater by struvite crystallization. The stripping equipment in CUSR was utilized for $\mathrm{CO}_{2}$ degasification from animal manure wastewater. The process of without and with magnesium addition for phosphate recovery was examined. Thermodynamic model predictions of struvite crystallization was undertaken to provide comparison. Seeding technology was employed to further enhance phosphate recovery efficiency. In addition, the character of chemical solids collected in CUSR was analyzed. 


\section{Materials and methods}

\section{Raw wastewater}

The raw wastewater was obtained from anaerobic digesters effluent of animal manure wastewater on a plant located near Beijing. The effluent was settled, filtered, and then stored in an icebox prior to the experiments. Table 1 shows the parameters of the raw wastewater sample.

Table 1

Characteristics of raw wastewater

\begin{tabular}{|c|c|c|}
\hline Parameter & Unit & Concentrations \\
\hline $\mathrm{COD}$ & {$\left[\mathrm{mg} / \mathrm{dm}^{3}\right]$} & 860 \\
\hline $\mathrm{NH}_{4}{ }^{+}-\mathrm{N}$ & {$\left[\mathrm{mg} / \mathrm{dm}^{3}\right]$} & 470 \\
\hline $\mathrm{PO}_{4}{ }^{3-}-\mathrm{P}$ & {$\left[\mathrm{mg} / \mathrm{dm}^{3}\right]$} & 96 \\
\hline $\mathrm{Mg}^{2+}$ & {$\left[\mathrm{mg} / \mathrm{dm}^{3}\right]$} & 46.6 \\
\hline $\mathrm{Ca}^{2+}$ & {$\left[\mathrm{mg} / \mathrm{dm}^{3}\right]$} & 24.6 \\
\hline Alkalinity $\left(\right.$ as $\left.\mathrm{CaCO}_{3}\right)$ & {$\left[\mathrm{mg} / \mathrm{dm}^{3}\right]$} & 3240 \\
\hline $\mathrm{pH}$ & - & $7.1 \pm 0.1$ \\
\hline
\end{tabular}

\section{Design and operation of continuous U-shape reactor}

To enhance the efficiency of struvite particles separation or collection, CUSR was designed and included aeration crystallization zone, crystal growth and settle zone, crystal and supernatant separation zone (Fig. 1). The experimental CUSR volume was $2 \mathrm{dm}^{3}$ $\left(1 \mathrm{dm}^{3}\right.$ of aeration crystallization zone; $0.5 \mathrm{dm}^{3}$ of crystal growth and settle zone; $0.5 \mathrm{dm}^{3}$ of crystal and supernatant separation zone). The aeration crystallization zone and crystal growth and settle zone was separated by clapboard that could reduce the influence of aeration crystallization area turbulence and improve struvite crystal growth. In crystal and supernatant separation zone, the upstream rate was gradually slower by the effect of tilted plate structure, therefore supernatant and chemical solids could separate effectively. The chemical solids could discharge intermittently at the bottom of CUSR.

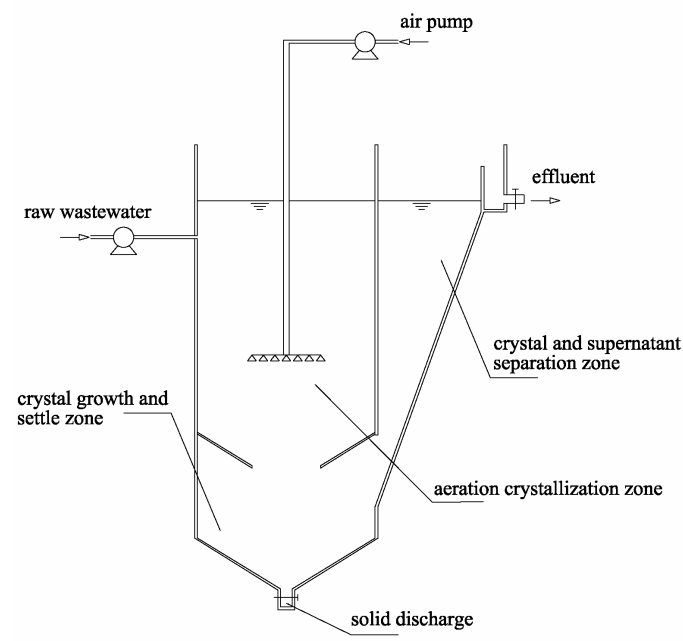

Fig. 1. Continuous U-shape reactor configuration diagram 
In the experiments, CUSR was controlled at the given experimental aeration flow rate $\left(5,10,15 \mathrm{dm}^{3} / \mathrm{min}\right)$ and hydraulic retention time (HRT) $(15,30,45,60,90 \mathrm{~min})$. To investigated $\mathrm{PO}_{4}{ }^{3-}-\mathrm{P}$ recovery efficiency, without and with magnesium addition process was performed, respectively. $\mathrm{MgCl}_{2}$ was used as magnesium source, mixed with the raw wastewater at different magnesium concentration and added into CUSR for struvite crystallization. For seeding technology, seeding materials (preformed struvite, sand, and stainless steel) was mixed with raw wastewater and added into CUSR.

\section{PHREEQC modeling calculation}

The composition of animal manure wastewater is complex and site specific. Iterative jar experiments are expensive and manpower-consuming. Several researchers have presented mathematical theoretical models of struvite crystallization to evaluate the reaction condition [13]. However, mathematical theoretical calculation, while effective, may be very complicated and time-consuming.

PHREEQC program, a low-temperature aqueous geochemical calculation computer program, can be used for modeling chemical precipitation-dissolution equilibrium [14]. In the research, the thermodynamic modeling calculation of struvite crystallization with PHREEQC program was performed. The compiled programs were calculated with PHREEQC.DAT database and the thermodynamic solubility product of struvite log $K_{s p}=-13.15\left(25^{\circ} \mathrm{C}\right)$ was adopted [15]. PHREEQC modeling predictions were compared with experimental results at different struvite crystallization conditions.

\section{Analytical methods}

The experimental samples were measured according to Standard Methods [16] for analysis. The collected chemical solids were washed with deionized water for 3 times, and dried in an oven at $40^{\circ} \mathrm{C}$ for 48 hours, and then analyzed by X-ray diffraction (XRD, Dmax/2400, Rigaku, Japan), Fourier transform infrared spectroscopy (FTIR, Nicolet 750, Nicolet, USA), scanning electron microscopy (SEM, S-3400N, Hitachi, Japan). The collected chemical solids were extracted with deionized water using centrifuge (200 r/min), and then the supernatant was analyzed to characterize the phosphate releasing ratio.

\section{Results and discussion}

\section{Without magnesium addition}

As $\mathrm{pH}$ increase by $\mathrm{CO}_{2}$ degasification, $\mathrm{Mg}^{2+}, \mathrm{NH}_{4}{ }^{+}, \mathrm{PO}_{4}{ }^{3-}$ contained in raw wastewater could spontaneous crystallization to form struvite without extra magnesium addition [7]. The HRT of CUSR is an important parameter for $\mathrm{CO}_{2}$ degasification and $\mathrm{pH}$ adjustment. The relationship between effluent $\mathrm{pH}, \mathrm{PO}_{4}{ }^{3-}-\mathrm{P}$ recovery ratio and HRT were investigated at different given experimental aeration flow rate $\left(5,10\right.$, and $15 \mathrm{dm}^{3} / \mathrm{min}$, respectively). The HRT of CUSR was operated at $15,30,45,60$, and 90, respectively.

The results (Fig. 2) showed when the HRT of CUSR operated at $60 \mathrm{~min}, \mathrm{PO}_{4}{ }^{3-}-\mathrm{P}$ recovery ratio could achieve $47-53 \%$ without extra magnesium addition. When aeration repelled dissolved $\mathrm{CO}_{2}$ out of raw wastewater, $\mathrm{pH}$ was increased (from 7.10 to 8.96 at $5 \mathrm{dm}^{3} / \mathrm{min}, 9.06$ at $10 \mathrm{dm}^{3} / \mathrm{min}, 9.13$ at $15 \mathrm{dm}^{3} / \mathrm{min}$ ) and $\mathrm{H}_{2} \mathrm{PO}_{4}{ }^{-}$transformed to $\mathrm{HPO}_{4}{ }^{2-}$ in solution. $\mathrm{HPO}_{4}{ }^{2-}$ could react with $\mathrm{Mg}^{2+}$ and $\mathrm{NH}_{4}{ }^{+}$to form struvite at solution $\mathrm{pH}$ in slightly alkaline media [17]. When operated HRT at $15 \mathrm{~min}$, only little phosphate could be 
recovered by struvite crystallization. $\mathrm{pH}\left(8.75\right.$ at $5 \mathrm{dm}^{3} / \mathrm{min}, 9.13$ at $10 \mathrm{dm}^{3} / \mathrm{min}, 9.20$ at $15 \mathrm{dm}^{3} / \mathrm{min}$ ) was increased significantly than that of raw wastewater due to carbonate removal by CUSR aeration. When operated HRT at $30 \mathrm{~min}, \mathrm{pH}\left(8.22\right.$ at $5 \mathrm{dm}^{3} / \mathrm{min}, 8.52$ at $10 \mathrm{dm}^{3} / \mathrm{min}, 8.71$ at $15 \mathrm{dm}^{3} / \mathrm{min}$ ) was lower than that of $15 \mathrm{~min}$ and $\mathrm{PO}_{4}{ }^{3-}-\mathrm{P}$ recovery ratio was higher than that of $15 \mathrm{~min}$. It was noted that struvite was formed in reactor as well as $\mathrm{H}^{+}$released into solution [18]. When operated HRT at $45 \mathrm{~min}$, both $\mathrm{PO}_{4}{ }^{3-}-\mathrm{P}$ recovery ratio and $\mathrm{pH}\left(8.87\right.$ at $5 \mathrm{dm}^{3} / \mathrm{min}, 9.03$ at $10 \mathrm{dm}^{3} / \mathrm{min}, 9.07$ at $\left.15 \mathrm{dm}^{3} / \mathrm{min}\right)$ were higher than that of $30 \mathrm{~min}$ as well as large amounts of struvite was observed. It was noted that the continuing carbonate removal rate was significantly higher than the $\mathrm{H}^{+}$release rate. When operated HRT at $60 \mathrm{~min}, \mathrm{PO}_{4}{ }^{3-}$-P recovery ratio and $\mathrm{pH}\left(8.96\right.$ at $5 \mathrm{dm}^{3} / \mathrm{min}, 9.06$ at $10 \mathrm{dm}^{3} / \mathrm{min}, 9.13$ at $15 \mathrm{dm}^{3} / \mathrm{min}$ ) was similar to that of $45 \mathrm{~min}$. The results indicated magnesium ions contained in wastewater was exhaust and the struvite crystallization process was ending [7]. When operated HRT at $90 \mathrm{~min}, \mathrm{PO}_{4}{ }^{3-}-\mathrm{P}$ recovery ratio and $\mathrm{pH}(8.94$ at $5 \mathrm{dm}^{3} / \mathrm{min}, 9.08$ at $10 \mathrm{dm}^{3} / \mathrm{min}, 9.15$ at $15 \mathrm{dm}^{3} / \mathrm{min}$ ) was close to that of $60 \mathrm{~min}$. This phenomenon might be due to the concentration of wastewater was steady and $\mathrm{CO}_{2}$ degasification process was ending.

The aeration flow rate of CUSR was also an important factor for $\mathrm{PO}_{4}{ }^{3-}-\mathrm{P}$ recovery. High aeration flow rate resulted in more carbonate removal from raw wastewater. The higher the aeration flow rate, the higher the effluent $\mathrm{pH}$ and $\mathrm{PO}_{4}{ }^{3-}-\mathrm{P}$ recovery efficiency. Korchef et al [8], Saidou et al [18] performed batch struvite precipitation by $\mathrm{CO}_{2}$ removal and observed similar experimental results as our CUSR studies.
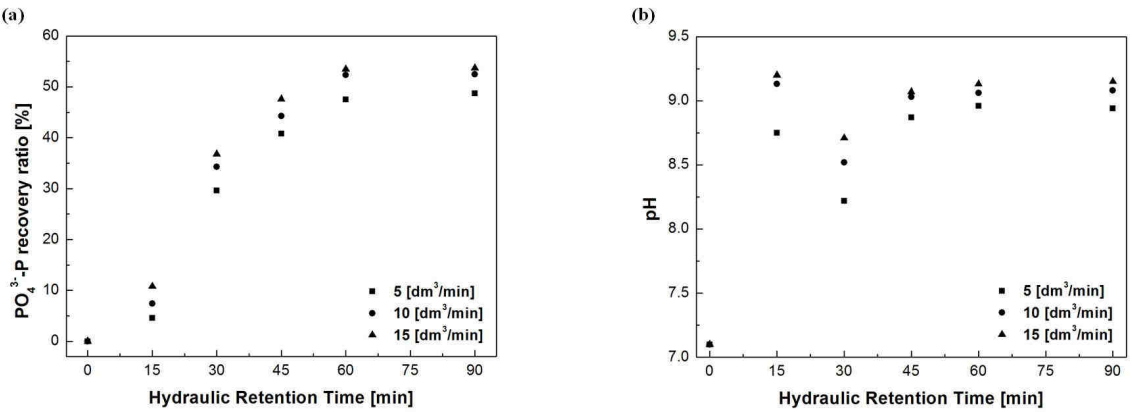

Fig. 2. $\mathrm{PO}_{4}{ }^{3-}-\mathrm{P}$ recovery of continuous $\mathrm{U}$-shape reactor without magnesium addition: a) $\mathrm{PO}_{4}{ }^{3-}-\mathrm{P}$ recovery ratio at different hydraulic retention time, b) Solution $\mathrm{pH}$ at different hydraulic retention time

\section{With magnesium addition}

For struvite crystallization, magnesium and ammonium concentrations are equally important to that of phosphate ion. Because enough ammonium was contained in raw wastewater, magnesium concentration was focussed as a limited constituent for struvite crystallization. Only repelled dissolved $\mathrm{CO}_{2}$ without extra magnesium addition, $\mathrm{PO}_{4}{ }^{3-}-\mathrm{P}$ recovery ratio was lower. To increase $\mathrm{PO}_{4}{ }^{3-}-\mathrm{P}$ recovery efficiency, $\mathrm{MgCl}_{2}$ was utilized as an extra magnesium source and added at given experimental concentration (27.7, 42.6, 57.5, $72.3 \mathrm{mg} / \mathrm{dm}^{3}$, respectively). The aeration flow rate was controlled at $5,10,15 \mathrm{dm}^{3} / \mathrm{min}$ and HRT was operated at $60 \mathrm{~min}$. 
The results (Fig. 3a) showed $\mathrm{PO}_{4}{ }^{3-}-\mathrm{P}$ recovery ratio was obvious increased with magnesium addition and achieve $80-86 \%$ at extra magnesium addition amount $57.5 \mathrm{mg} / \mathrm{dm}^{3}$. With an increase in $\mathrm{Mg}^{2+}$ concentration from 27.7 to $57.5 \mathrm{mg} / \mathrm{dm}^{3}, \mathrm{PO}_{4}{ }^{3-}-\mathrm{P}$ recovery efficiency increased significantly. The addition of $\mathrm{Mg}^{2+}$ could induce high struvite crystallization potential and $\mathrm{Mg}^{2+}$ concentration was an important constituent for struvite crystallization as elucidated elsewhere [19]. With an increase in $\mathrm{Mg}^{2+}$ concentration from 57.5 to $72.3 \mathrm{mg} / \mathrm{dm}^{3}, \mathrm{PO}_{4}{ }^{3-}-\mathrm{P}$ recovery efficiency did not increase obviously. The excess added magnesium could result in region high supersaturation of CUSR, which further caused separation issue between small struvite particles and supernatant [20]. If the supersaturation is too high, faster reaction kinetics of struvite can cause numerous crystal nucleation and retard crystal growth larger. It will result in the formation of small crystal particles and cause the separation problems for $\mathrm{PO}_{4}{ }^{3-}-\mathrm{P}$ recovery.

To provide a comparison, PHREEQC thermodynamic modeling calculation was undertaken. The saturation index $(S I)$ of struvite was calculated to judge the supersaturation of a precipitate phase in solution. $S I$ is defined as $S I=\log \left(\mathrm{IAP} / K_{s p}\right)$, where IAP is the free ionic activities product and $K_{s p}$ is the thermodynamic solubility product constant. The reaction solution is supersaturated if $S I>0$ [14]. Under a set of chemically defined solution conditions, SI calculation of struvite was used as an indicator to provide a prediction.

The results (Fig. 3b) showed the modeling calculation SI of struvite increased with an increase in $\mathrm{Mg}^{2+}$ concentration. For struvite crystallization, the addition of magnesium ion could increase the supersaturation and crystallization potential. PHREEQC predictions trend was in qualitative agreement with CUSR experimental results. The modeling calculation of struvite crystallization can provide a theoretical guide for operational parameters design, although practical animal manure wastewater treatment is complicated. When modeling data are entered in PHREEQC program, it is convenient to perform various analyses for optimizing struvite crystallization technical parameters. Wang et al [19] conclude PHREEQC program could be used to guide the design and operation of struvite crystallization process for phosphate recovery.
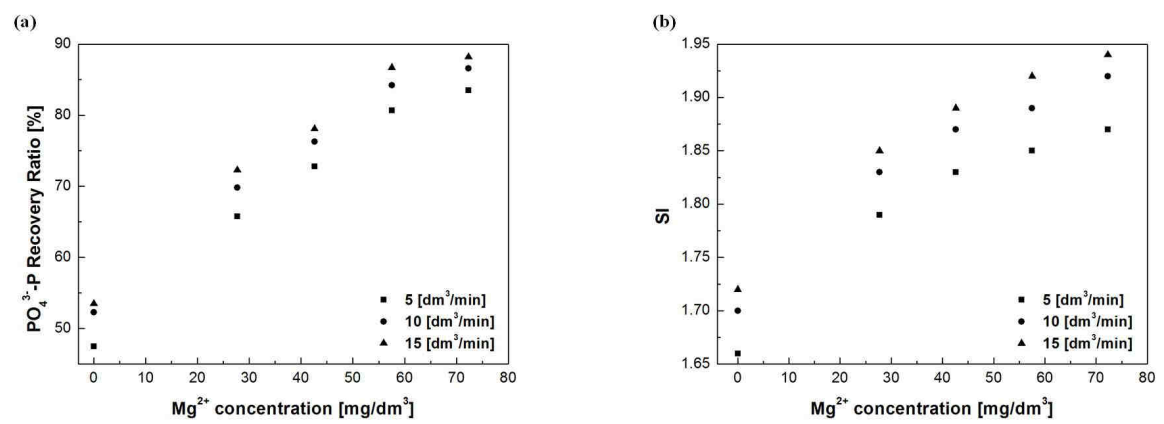

Fig. 3. $\mathrm{PO}_{4}{ }^{3-}-\mathrm{P}$ recovery of continuous $\mathrm{U}$-shape reactor with magnesium addition: a) $\mathrm{PO}_{4}{ }^{3-}-\mathrm{P}$ recovery ratio at different magnesium addition amount, b) modeling saturation index $(S I)$ at different magnesium addition amount 


\section{Seeding technology}

Compared with only $\mathrm{CO}_{2}$ degasification, the process of extra magnesium addition could obvious increase $\mathrm{PO}_{4}{ }^{3-}-\mathrm{P}$ recovery ratio. In order to further enhance $\mathrm{PO}_{4}{ }^{3-}-\mathrm{P}$ recovery efficiency, seeding technology for struvite crystallization was attempted in CUSR. Preformed struvite, sand, and stainless steel powder were selected as seeding materials. The magnesium addition amount was $57.5 \mathrm{mg} / \mathrm{dm}^{3}$. The aeration flow rate was controlled at 5 , $10,15 \mathrm{dm}^{3} / \mathrm{min}$ and HRT was operated at $60 \mathrm{~min}$.

The results (Fig. 4) showed high $\mathrm{PO}_{4}{ }^{3-}-\mathrm{P}$ recovery efficiency was obtained using seeding technology. Figure $4 \mathrm{a}$ showed all of three seeding materials could enhance $\mathrm{PO}_{4}{ }^{3-}-\mathrm{P}$ recovery efficiency and preformed struvite was the most effective seeding material. Because physical-chemical characterization of preformed struvite was similar to struvite crystal in CUSR, it could increase crystal growth rate and crystal size more effective than other seeding materials. Figure $4 \mathrm{~b}$ showed the optimal addition amount of preformed struvite was $0.5 \mathrm{~g} / \mathrm{dm}^{3}$. Any overdosing of preformed struvite did not bring further significant increases in $\mathrm{PO}_{4}{ }^{3-}$-P recovery ratio. At lower seeding addition amount, both crystal nucleation and growth mechanisms affect struvite crystallization. This could reduce the losses of small struvite crystal particles and result in $\mathrm{PO}_{4}{ }^{3-}-\mathrm{P}$ recovery ratio increasing [21]. In contrast, at higher seeding addition amount, the mechanism of crystal nucleation has a weaker effect than does crystal growth. No improvement in $\mathrm{PO}_{4}{ }^{3-}-\mathrm{P}$ recovery ratio would be expected [12]. Liu et al [10] reported the seeding process could improve struvite formation rate and enhance struvite crystal growth.
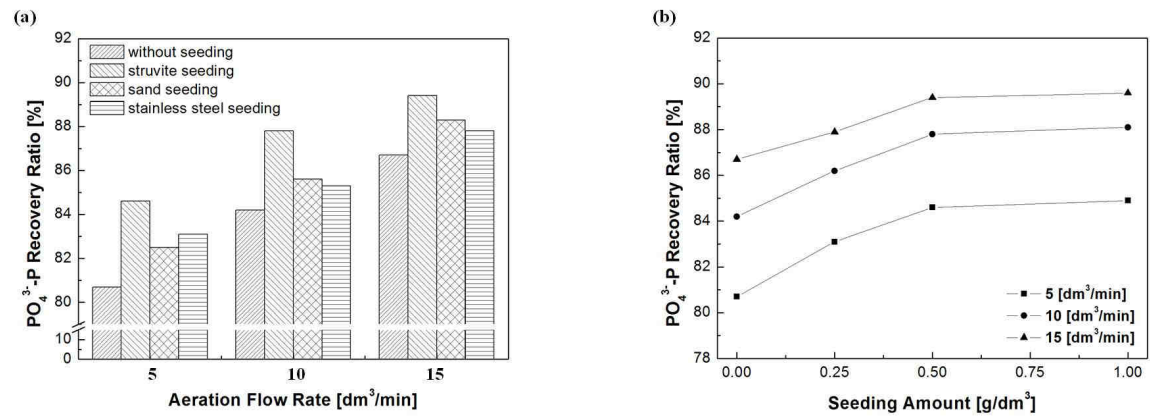

Fig. 4. $\mathrm{PO}_{4}{ }^{3-}-\mathrm{P}$ recovery efficiency of seeding technology at different factors: a) $\mathrm{PO}_{4}{ }^{3-}-\mathrm{P}$ recovery ratio at different seeding materials (seeding amount $=0.5 \mathrm{~g} / \mathrm{dm}^{3}$ ), b) $\mathrm{PO}_{4}{ }^{3-}-\mathrm{P}$ recovery ratio at different addition amount of preformed struvite

\section{Chemical solids character}

Surface characterization analysis was employed to characterize the chemical solids obtained in CUSR. XRD and FTIR analysis (Fig. 5) demonstrated struvite was the dominant composition of chemical solids, although some impurities presence in raw wastewater. XRD analysis (Fig. 5a) indicated the prominent characteristic peaks of chemical solids were close to that of struvite pattern standard (JCPDS 15-0762). FTIR analysis (Fig. 5b) showed the infrared spectrum of chemical solids was conformed to that of standard struvite pattern. The $3700-2500 \mathrm{~cm}^{-1}$ band indicated the presence of crystalline hydrate. The $2355 \mathrm{~cm}^{-1}$ band 
was ascribed to the water-phosphate hydrogen bonding. The $1683 \mathrm{~cm}^{-1}$ band indicated the water $\mathrm{HOH}$ bending region. The $1436 \mathrm{~cm}^{-1}$ band was the ammonium characteristic band. The 1002 and $569 \mathrm{~cm}^{-1}$ bands were the $\mathrm{PO}_{4}{ }^{3-}$ band. The $762 \mathrm{~cm}^{-1}$ bands were the water-water hydrogen bonding. SEM analysis (Fig. 5c) showed the surface of the orthorhombic crystal was coarse and its size was irregular (30-100 um length).

(a)

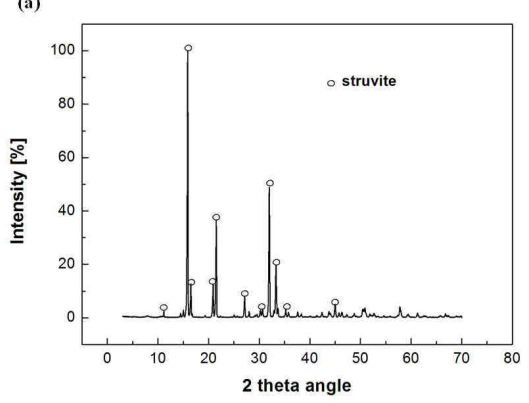

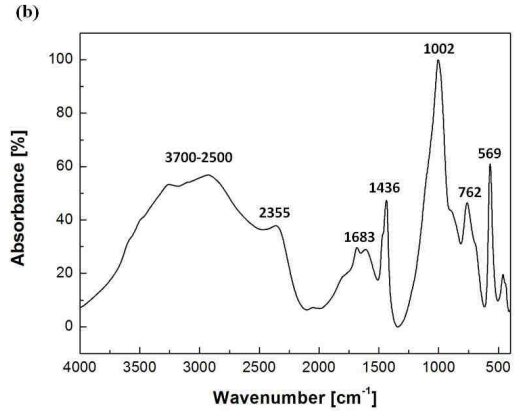

(c)

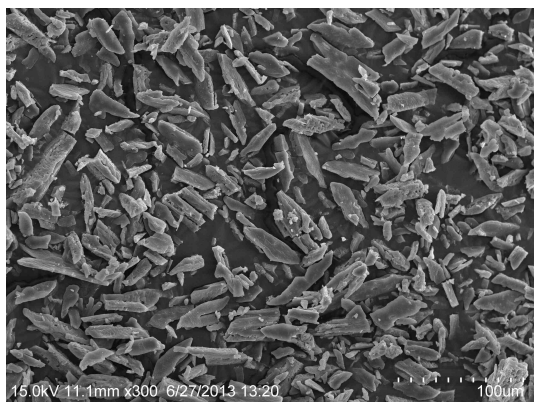

Fig. 5. Surface characterization analysis of chemical solids: a) X-ray diffraction analysis, b) Fourier transforms infrared spectroscopy analysis, c) scanning electron microscopy analysis

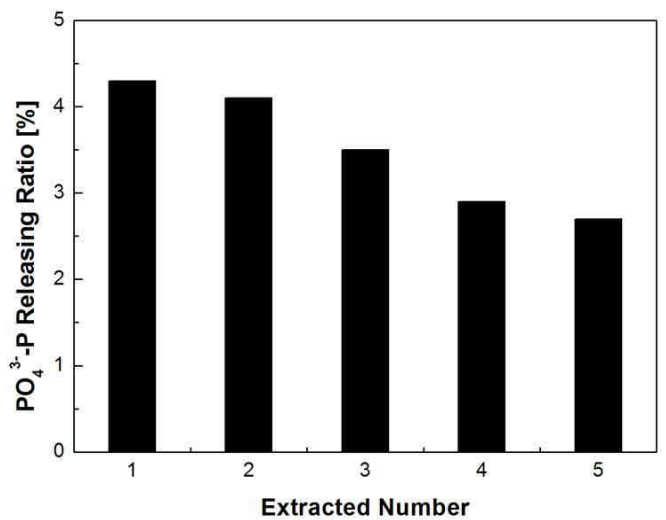

Fig. 6. Water extraction analysis of chemical solids 
Water extraction analysis was performed to characterize the available of chemical solids obtained in CUSR. The water extracted numbers for chemical solids was over 1-5 times. The experimental results (Fig. 6) showed phosphate releasing ratio was decreased slightly with extracted numbers increasing. The $\mathrm{PO}_{4}{ }^{3-}-\mathrm{P}$ releasing ratio of 5 th time was $1.6 \%$ lower than that of 1 st time and the total $\mathrm{PO}_{4}{ }^{3-}-\mathrm{P}$ releasing ratio over $1-5$ times were $17.5 \%$. Water extraction analysis indicated chemical solids recovery from animal manure wastewater could release $\mathrm{PO}_{4}{ }^{3-}$-P slowly and be available as slow-release fertilizer. Latifian et al [22] investigated the physical and chemical properties of struvite and obtained similar results as our research.

\section{Conclusions}

Struvite crystallization process with $\mathrm{CO}_{2}$ degasification CUSR was applied for $\mathrm{PO}_{4}{ }^{3-}$-P recovery from anaerobic digesters effluent of animal manure wastewater and the following conclusions were drawn.

For CUSR operation, when the HRT of CUSR controlled at $60 \mathrm{~min}, \mathrm{PO}_{4}{ }^{3-}$-P recovery ratio could achieve $47-53 \%$ without magnesium addition. With extra magnesium addition, $\mathrm{PO}_{4}{ }^{3-}-\mathrm{P}$ recovery ratio could significantly increase and achieve $80-86 \%$ at $\mathrm{Mg}^{2+}$ addition amount $57.5 \mathrm{mg} / \mathrm{dm}^{3}$. PHREEQC modeling predictions trend of struvite crystallization was in qualitative agreement with CUSR experimental results and the modeling calculation can provide a theoretical guide for operational parameters design. High $\mathrm{PO}_{4}{ }^{3-}-\mathrm{P}$ recovery efficiency could be obtained using seeding technology and preformed struvite was the most effective seeding material. Surface characterization analysis demonstrated struvite was the dominant composition of chemical solids obtained in CUSR. Water extraction analysis indicated chemical solids recovery from animal manure wastewater could release $\mathrm{PO}_{4}{ }^{3-}-\mathrm{P}$ slowly and be available as slow-release fertilizer.

\section{Acknowledgements}

The work was supported by a grant from the Specialized Research Fund for the Doctoral Program of Higher Education (20120008120013), Beijing Natural Science Foundation (6144026), Chinese Universities Scientific Fund of China Agricultural University (2011JS169). Thanks to the Analytical Instrumentation Center of Peking University.

\section{References}

[1] Gilbert N. Environment: The disappearing nutrient. Nature. 2009;461:716-718. DOI: 10.1038/461716a.

[2] Cordell D, Rosemarin A, Schroder JJ, Smit AL. Towards global phosphorus security: A systems framework for phosphorus recovery and reuse options. Chemosphere. 2011;84:747-758. DOI: 10.1016/j.chemosphere.2011.02.032.

[3] Paerl HW, Huisman J. Climate - blooms like it hot. Science. 2008;320:57-58. DOI: 10.1126/science. 1155398 .

[4] Szogi AA, Vanotti MB. Prospects for phosphorus recovery from poultry litter. Bioresource Technol. 2009;100:5461-5465. DOI: 10.1016/j.biortech.2009.03.071.

[5] Rittmann BE, Mayer B, Westerhoff P, Edwards M. Capturing the lost phosphorus. Chemosphere. 2011;84:846-853. DOI: 10.1016/j.chemosphere.2011.02.001.

[6] Le Corre KS, Valsami-Jones E, Hobbs P, Parsons SA. Phosphorus recovery from wastewater by struvite crystallization: A review. Crit Rev Environ Sci Technol. 2009;39:433-477. DOI: 10.1080/10643380701640573. 
[7] Song YH, Qiu GL, Yuan P, Cui XY, Peng JF, Zeng P, et al. Nutrients removal and recovery from anaerobically digested swine wastewater by struvite crystallization without chemical additions. J Hazard Mater. 2011;190:140-149. DOI: 10.1016/j.jhazmat.2011.03.015.

[8] Korchef A, Saidou H, Ben Amor M. Phosphate recovery through struvite precipitation by $\mathrm{CO}_{2}$ removal: Effect of magnesium, phosphate and ammonium concentrations. J Hazard Mater. 2011;186:602-613. DOI: 10.1016/j.jhazmat.2010.11.045.

[9] Shepherd TA, Burns RT, Moody LB., Raman DR, Stalder KJ. Development of a bench-scale air sparged continuous flow reactor for struvite precipitation from two different liquid swine manure storage systems. Appl Eng Agric. 2009;25:425-430.

[10] Liu ZG, Zhao QL, Lee DJ, Yang N. Enhancing phosphorus recovery by a new internal recycle seeding map reactor. Bioresource Technol. 2008;99:6488-6493. DOI: 10.1016/j.biortech.2007.11.039.

[11] Iqbal M, Bhuiyan H, Mavinic DS. Assessing struvite precipitation in a pilot-scale fluidized bed crystallizer. Environ Technol. 2008;29:1157-1167. DOI: 10.1080/09593330802075452.

[12] Zhang T, Ding LL, Ren HQ, Xiong X. Ammonium nitrogen removal from coking wastewater by chemical precipitation recycle technology. Water Res. 2009;43:5209-5215. DOI: 10.1016/j.watres.2009.08.054.

[13] Gadekar S, Pullammanappallil P. Validation and applications of a chemical equilibrium model for struvite precipitation. Environ Model Assess. 2010;15:201-209. DOI: 10.1007/s10666-009-9193-7.

[14] Zhang T, Ding LL, Ren HQ, Guo ZT, Tan J. Thermodynamic modeling of ferric phosphate precipitation for phosphorus removal and recovery from wastewater. J Hazard Mater. 2010;176:444-450. DOI: 10.1016/j.jhazmat.2009.11.049.

[15] Celen I, Buchanan JR, Burns RT, Robinson RB, Raman DR. Using a chemical equilibrium model to predict amendments required to precipitate phosphorus as struvite in liquid swine manure. Water Res. 2007;41:1689-1696. DOI: 10.1016/j.watres.2007.01.018.

[16] APHA, Standard methods for the examination of water and wastewater. 22nd ed. Washington DC, USA: Water Environment Federation; 2012.

[17] Mijangos F, Kamel M, Lesmes G, Muraviev DN. Synthesis of struvite by ion exchange isothermal supersaturation technique. React Funct Polym. 2004;60:151-161. DOI: 10.1016/j.reactfunctpolym.2004.02.019.

[18] Saidou H, Korchef A, Ben Moussa S, Ben Amor M. Struvite precipitation by the dissolved CO2 degasification technique: Impact of the airflow rate and $\mathrm{pH}$. Chemosphere. 2009;74:338-343. DOI: 10.1016/j.chemosphere.2008.09.081.

[19] Wang JS, Song YH, Yuan P, Peng JF, Fan MH. Modeling the crystallization of magnesium ammonium phosphate for phosphorus recovery. Chemosphere. 2006;65:1182-1187. DOI: 10.1016/j.chemosphere.2006.03.062.

[20] Adnan A, Koch FA, Mavinic DS. Pilot-scale study of phosphorus recovery through struvite crystallization ii: Applying in-reactor supersaturation ratio as a process control parameter. J Environ Eng Sci. 2003;2:473-483. DOI: 10.1139/S03-048.

[21] Kim D, Ryu HD, Kim MS, Kim J, Lee SI. Enhancing struvite precipitation potential for ammonia nitrogen removal in municipal landfill leachate. J Hazard Mater. 2007;146:81-85. DOI: 10.1016/j.jhazmat.2006.11.054

[22] Latifian M, Liu J, Mattiasson B. Struvite-based fertilizer and its physical and chemical properties. Environ Technol. 2012;33(24):2691-2697. DOI: 10.1080/09593330.2012.676073.

\title{
ODZYSKIWANIE FOSFORANÓW ZE ŚCIEKÓW OBORNIKA ZA POMOCĄ KRYSTALIZACJI STRUWITU I ODGAZOWANIA Z $\mathrm{CO}_{2}$ W REAKTORZE
}

\begin{abstract}
Abstrakt: Problem uwalniania fosforu jest związany $\mathrm{z}$ ochroną środowiska i bezpieczeństwem żywności. Krystalizacja struwitu jest przydatną technologią odzysku fosforanów ze ścieków. W opisanych badaniach proces krystalizacji struwitu zastosowano do odzyskiwania fosforanów z gnojowicy, do tego celu wykorzystano reaktor ciągłego odgazowywania $\mathrm{CO}_{2} \mathrm{w}$ kształcie litery U (CUSR). Wyniki wskazują, że wskaźnik odzysku $\mathrm{PO}_{4}{ }^{3-} \mathrm{może}$ osiągnąć 47-53\% P bez dodatku magnezu, gdy kontrolowany, hydrauliczny czas retencji CUSR wynosi 60 min. Po wprowadzeniu magnezu w ilości $57,5 \mathrm{mg} / \mathrm{dm}^{3}$ wskaźnik odzysku $\mathrm{PO}_{4}{ }^{3-}$ może osiągnąć $80-86 \% \mathrm{P}$. Przewidywania modelu PHREEQC dotyczące krystalizacji struwitu był bliskie wynikom doświadczalnym CUSR. Obliczenia teoretyczne $\mathrm{z}$ wykorzystaniem modelu mogą stanowić wskazówkę do ustalania rzeczywistych
\end{abstract}


parametrów eksploatacyjnych. Struwit otrzymany z gnojowicy może mieć zastosowanie w nasiennictwie. Analiza ekstrakcyjna wykazała, że materiał ten może powoli uwalniać $\mathrm{PO}_{4}{ }^{3-}-\mathrm{P}$ i dzięki temu znajduje zastosowanie jako nawóz.

Słowa kluczowe: gnojowica, odgazowanie $\mathrm{CO}_{2}$, reaktor ciągły w kształcie litery $\mathrm{U}$ (CUSR), fosforan, krystalizacja struwitu 